\title{
A study on incorporating ICT in teaching methodologies at universities of Quetta
}

\author{
Nausheen Saeed $^{1 *}$, Farrukh Nasim ${ }^{2}$, Walayat Hussain ${ }^{3}$, Samina Azeem ${ }^{1}$ \\ ${ }^{1}$ Lecturer, Department of Computer Science, Sardar Bahadur Khan Women University, Quetta \\ ${ }^{2}$ IT Coordinator, Save the Children USA, Quetta Program Office \\ ${ }^{3}$ Assistant Professor, Department of Computer Science, Balochistan University of Information \& Technology, Quetta \\ *Corresponding author E-mail: nausheensaeed1@hotmail.com
}

Copyright $\odot 2015$ Nausheen Saeed et al. This is an open access article distributed under the Creative Commons Attribution License, which permits unrestricted use, distribution, and reproduction in any medium, provided the original work is properly cited.

\begin{abstract}
This paper presents a study on the use of ICT in teaching methodology by the faculty of universities in Quetta, Pakistan. A Survey about the impact of ICT usage was conducted in three major public universities of Quetta - University Of Balochistan, Sardar Bahadur Khan Women University, and Balochistan University of Information Technology, Engineering and Management Sciences, focusing the faculty and the students. The study shows that ample ICT facilities are available to the faculties in these universities and the teachers incorporate different ICT tools in their teaching methodologies. Teachers and students believe that ICT has played a vital role in improving the quality of education while there remain some areas of improvement like University web portals, access to digital libraries for the students and online student management systems.
\end{abstract}

Keywords: Human Computer Interaction; Teaching Methodology; Universities; Quetta; Information and Communication Technology (ICT).

\section{Introduction}

Like other fields of life, Information and Communication Technology (ICT) is playing an important role in the field of education all over the world, especially in higher education programs. Several studies were carried out in developed and under-developed countries focusing the impact of ICT in education.

Quetta, the capital of geographically largest but least populated province of Pakistan hosts three public universities providing educational services to national and international students. All three universities (University Of Balochistan, Sardar Bahadur Khan Women University, and Balochistan University of Information Technology, Engineering and Management Sciences) offer higher education courses in different disciplines.

The appropriate use of ICT in universities worldwide has proven to be effective in higher education - if implemented and used properly. Pakistan, although an underdeveloped country, saw a major advancement in the field of ICT over the last 15 years. Higher Education Commission - the primary regulator of higher education in Pakistan has identified "Incorporating Technology in Education - ITE" as second major component of National Academy of Higher Education. http://www.hec.gov.pk/InsideHEC/Divisions/LearningInnovation/NAHE/Pages/ITE.aspx

\section{Literature review}

ICT comprises of numerous technological tools, methods and resources that are used for creating, storing, managing, communicating and analyzing the information. For education, ICT can not only play an important role to accomplish important activities like teaching, learning, research, administering, curriculum development and collaborative learning [1] but also determine the future of education system through major restructuring in methods and management. Use of smart services and technologies in education can improve the efficiency, effectiveness and productivity. [2] 
Although institutions have extensively adopted ICT in higher education since mid-1990s all over the world, it is still believed that desirable outcomes have not been achieved yet. There have been certain barriers, including but not limited to technological constraints, IT management problems, individual and cultural factors. [3]. Another major challenge in integrating ICT to higher education may be the conflict between teacher-centered and student-centered pedagogies. By better understanding this conflict, appropriate measures can be taken to support teaching and learning while providing a better awareness and access to ICT resources [4]

While there is an established fact of ICT integration into higher education, it is equally important to measure the degree of this integration. According to [5], the major indicator for this integration can be the innovativeness of use of ICT for teaching and learning. There have been cases when the educators have positively used ICT to transform, innovate, enhance or replace their teaching practice. The educators use different ICT tools to support their teaching methodologies like productivity software, web resources, email, multi-media etc.

The world has seen a great advancement in the field of science. To support the scientific learning process, use of ICT equipment, smart boards, mobile devices and specifically simulations have been very effective. Simulator is "a program that contains a model of system (natural or artificial; e.g., equipment) or a process" [6] Simulations are known for their use as enhancements or replacement of traditional means of testing the results. They have gained popularity in the classrooms as well to better understand the scientific portion of the curriculum. Apart from their effective use in teaching and testing, simulations are believed not to be the entire replacement of laboratory skills that one can acquire through experience only.

One cannot incorporate ICT into higher education in a blink of an eye. It is a gradual, time-consuming and ubiquitous process that needs intensive care and attention. Institutions face several barriers such as extensive external pressure, urgency in the implementation process, budget restrictions and lack of an effective link between the purpose, people and pedagogy inside the institution [7]

Studies have shown that the teachers should have the adaptability to know how to use ICT in their teaching methodology [8].It does not necessarily mean that ICT knowledge is the only pre-requisite for effective teaching methodologies, equal emphasis should be given to pedagogy and technology in order to achieve better results. According to [9], the successful implementation of ICT in education is divided into three major lines: availability of technical facilities, using these facilities and using technology in greater depth.

Although there has been a great investment in bringing ICT to higher education in developed and underdeveloped countries, there is still not enough research material available on this subject. On the other hand, limited literature is available on actually determining the effectiveness of ICT in higher education. Among other barriers in implementing ICT in higher education, the reluctance in the faculty members of non-scientific disciplines and lack of enough technical support may also pose a challenge to integration technology in education.

\section{Methodology}

The study was carried out by surveying the faculty of three universities. An online survey was conducted for different faculties to gather information about the availability, ability and use of ICT in their teaching methodologies. Another questionnaire was conducted for the students of these universities to verify how ICT was incorporated into the teaching methodologies. Google forms and Google Analytics was used as a primary tool to conduct and conclude the surveys.

The survey for the faculty involved closed and some open ended questions in the following 3 categories:

1) Evaluating the teacher's own ICT skills

2) Use of ICT in their teaching methodologies, and

3) Use of ICT to interact with students

The first section of teacher's survey focused questions regarding ability of using computing and peripheral device, proficiency with software, Internet and electronic collaboration tools. Second part of the survey inquired about the use of ICT in their teaching methodologies, like, how long have they been working with ICT, availability of ICT facilities in classrooms and labs, actual use of available ICT facilities in teaching methodology, their own assessment of effectiveness of ICT in teaching methodology, use of digital libraries and simulators. The third part of faculty survey explored different ways how the faculty interact with the students using ICT tools like how do they use ICT tools to interact with the students, provide instructional material to them, collect students assignments and use web portals/ emails to interact with and evaluate the students.

The survey for the students, relatively simpler and concise focused on collecting students' responses regarding their teachers' use of computers, software and simulations during lectures, availability of ICT facilities in the campuses, available means of interaction with teachers, access to university portals, submitting their assignments and their own views about effectiveness of ICT in education and means to improve it.

Based on the questions involved in the study, qualitative and quantitative research techniques were applied to evaluate the use of ICT and measure its effectiveness in teaching methodologies. 


\section{Results/ findings}

\subsection{Faculty survey}

Based on faculty survey, it was observed that $83 \%$ faculty members were conversant in using desktops/ laptops, $58 \%$ could use tablets, while $67 \%$ faculty were using smartphones. Out of the faculty member, able to use computers, the percentage of teachers able to use scanners, printers, copiers and multimedia projectors was $83 \%, 92 \%, 50 \%$ and $75 \%$ respectively. All of them could use word processing software, $83 \%$ can use spreadsheets and $92 \%$ can work with presentation software. Staff also exhibited a high level of proficiency in using Internet tools. $92 \%$ could use Web browsers, $83 \%$ used audio/video messengers, 92\% had their personal email accounts and 75\% faculty used social media. There seemed to be a lack of use in electronic collaboration tools such as Document collaboration, workflows and electronic boards whose percentage remained $50 \%, 40 \%$ and $30 \%$ respectively.

\begin{tabular}{ll}
\hline Computer & $83 \%$ \\
\hline Audio and Visual aid (including Multimedia Projector) & $100 \%$ \\
Internet access & $75 \%$ \\
Smart boards & $8 \%$ \\
Conferencing tools & $8 \%$ \\
Social networks(facebook,youtube,twitter,orkut) & $33 \%$ \\
Simulation & $50 \%$ \\
Other & $0 \%$ \\
\hline
\end{tabular}

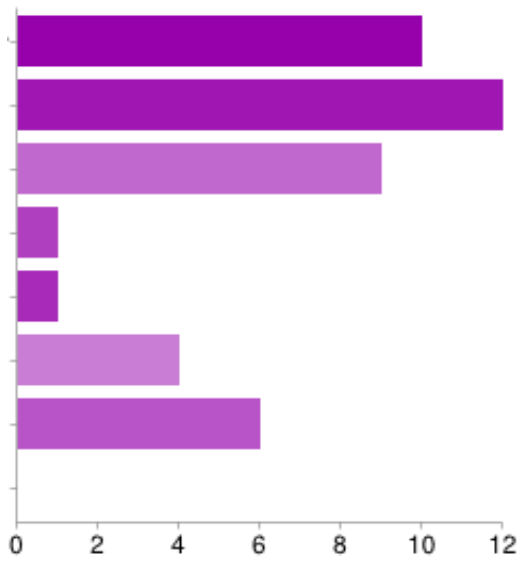

Fig. 1: Actual Use of ICT in Teaching Methodology.

The following chart and table shows the actual use of ICT facilities by the faculty in their teaching methodology:

The prime sources to incorporate research in the lectures were digital libraries, Internet and books. $92 \%$ faculty had access to online research journals through University infrastructure. $8 \%$ faculty claimed that use of simulations did not apply to their subjects, while out of the rest, $67 \%$ use simulators to aid their lectures.

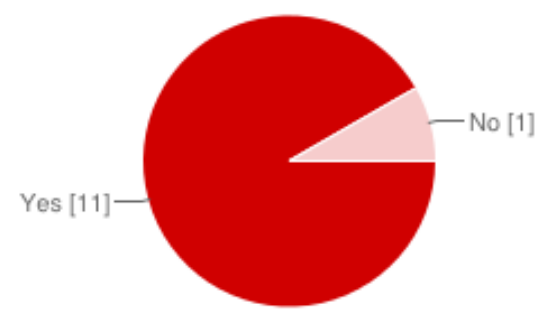

Fig. 2: Access to Online Research Journals.

Email was observed to be the prime source of interaction with the students. $42 \%$ faculty had their official email accounts and $8 \%$ had the provision of University web portal to interact with students. The students submit their assignments via email (83\%) and/or in printed form (92\%). None of the university had a comprehensive solution of examination and evaluation of students through software however $33 \%$ faculty had the facility of automated exams evaluation but the exams were conducted manually. $8 \%$ faculty had available web portals for their departments where the students can interact with them directly. 


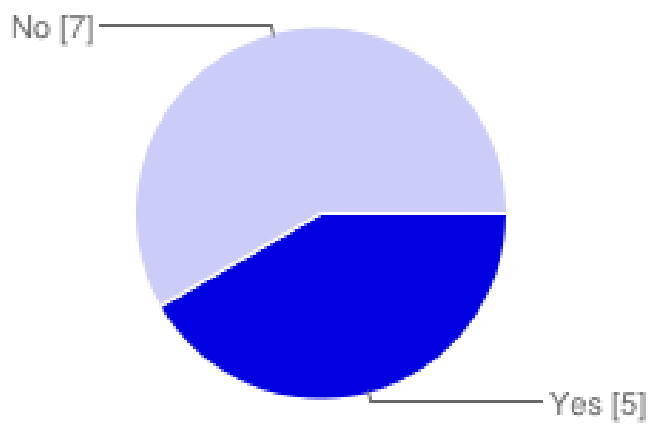

Fig. 3: Faculty Having Official Email Ids.

\subsection{Students survey}

The students of the three Universities were surveyed to verify the faculty's response. 83\% students responded that their teachers use computers in delivering their lectures. The available ICT facilities (dedicated for students) can be summarized as follows:

\begin{tabular}{ll}
\hline Computer & $36 \%$ \\
\hline Internet & $30 \%$ \\
Printing & $19 \%$ \\
Online Storage space for files & $0 \%$ \\
Access to Digital Libraries & $14 \%$ \\
Other & $0 \%$ \\
\hline
\end{tabular}

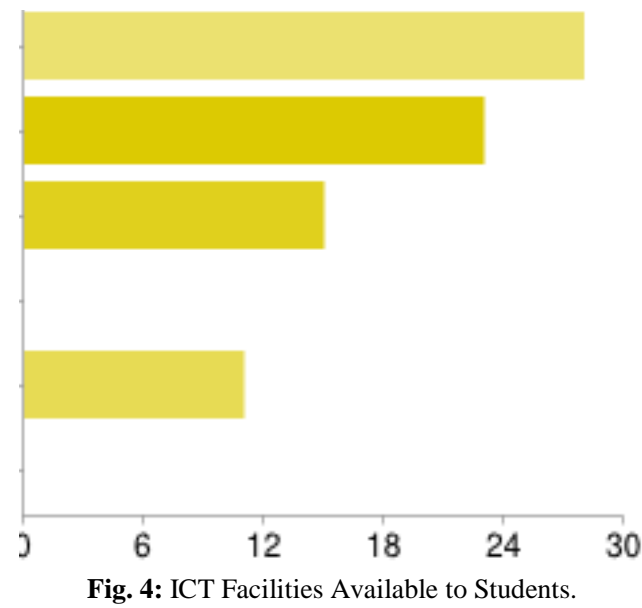

$85 \%$ teachers preferred PowerPoint presentations to be their prime tool, $9 \%$ used video conferencing and $6 \%$ used other means to deliver their lectures. 57\% students used to submit their assignments in printed form, $39 \%$ through email and $4 \%$ used online portals.

$47 \%$ students had access to university portals and $37 \%$ students endorsed that their teachers use simulations to supplement their lectures.

\section{Conclusions}

It is an established fact that all three universities have appropriate ICT resources for the faculty, however, the provision of ICT tools \& equipment to the students remained average. Faculty and students both agreed to the importance of using ICT in education. The universities have appropriate access to online research journals and video conferencing sites.

The study also revealed some potential areas of improvement like implementing University web portals, online collaboration systems, providing official email addresses to all faculty members, encouraging teachers to use simulations and implementing online systems for student management. 


\section{Acknowledgement}

We like to thank all faculty members and students who contributed their precious time to take the survey. Special thanks to our research supervisor Mr. Walayat Hussain, Assistant Professor, BUITEMS who provided valuable support in making this study happen.

\section{References}

[1] K. F. V. \&. Jahani, "Application of ICT in University Curriculum Development," International Conference on Education Technology and Computer, pp. p60-64, 2009.

[2] A. K. W. L. Panjai Tantatsanawong, "Enabling Future Education with Smart Service," in Annual SRII Global Conference, 2011. http://dx.doi.org/10.1109/srii.2011.63.

[3] M. Q. Hud, "'ICT Implementation Barriers and Organizational Issues in Islamic-based Higher Education Institution: The Case of Syarif Hidayatullah State Islamic University (UIN) Jakarta".

[4] L. H. -. M. Webb, "Integrating ICT to higher education in China Integrating ICT to higher education in China" From the perspective of Activity Theory," Springer Science + Business Media, LLC, pp. p143-161, 2009.

[5] P. V. P. Jef Peeraer, "Measuring integration of information and communication technology in education: An item response modeling approach," Elsevier Ltd, pp. p1247-1259, 2011.

[6] W. R. v. J. J. T. v. d. V. Nico Rutten, "The learning effects of computer simulations in science education," Elsevier Ltd, pp. p136-153, 2011.

[7] P. M. M. B. M. O. \&. B. K. Bjorn Stensaker, "Use, updating and integration of ICT in higher education: Linking purpose, people and pedagogy," Springer, pp. p417-433, 2006.

[8] C. B. Mammar Belagra, "Using ICT in higher education: Teachers of Electrical Engineering Department at the University of Bechar: Case Study".

[9] E. v. D. W. D. S. D. F. L. A. v. P. S. P. D. J. P. E. S. W. v. V. \&. M. v. d. V. Jenny Brakels, "Implementing ICT in Education faculty-wide," European Journal of Engineering Education, pp. p63-76, 2002.

[10] A. Dewan, "Scope of Technology in Higher Education in India: A Study," Vols. 978-1-4244-7361-8/10, pp. p234-235, 2010. http://dx.doi.org/10.1109/t4e.2010.5550105.

[11] C. M. J. G. Despina Galanouli, "Teachers perceptions of effectiveness of ICT-competence training," Elsevier, pp. p63-79, 2003.

[12] K. F. V. \&. Jahani, ""Application of ICT in University Curriculum Development," in International Conference on Education Technology and Computer, 2009. 